\title{
The Attitude of Students Towards T.V Advertisements on Economic and Social Aspects
}

\author{
Dr. Anuradha Sharma ${ }^{1} \&$ Ms. Surbhi ${ }^{2 *}$ \\ ${ }^{1}$ Professor, ${ }^{2}$ Research Scholar, \\ ${ }^{1,2}$ Department of Community Education \& Disability Studies, Panjab University, 160014, Chandigarh, India. \\ Email: surbhi.arora130@gmail.com ${ }^{2 *}$
}

DOI: http://doi.org/10.38177/ajast.2021.5310

Copyright: () 2021 Anuradha Sharma \& Surbhi. This is an open accessarticle distributed under the termsof the Creative Commons Attribution License, which permitsunrestricted use, distribution, andreproduction in any medium,provided the original author andsource are credited.

The study was undertaken with a purpose to study the attitude of students towards T.V advertisements on economic and social aspects. The sample comprised of 100 students selected by random sampling technique from Panjab University, Chandigarh. The findings revealed that advertisement helps to raise our standard of living whereas in social aspect an advertisement produces potentially negative side effects. Apart from that, the research serves as a good baseline for future research.

Keywords: Advertisements, Perspective, Students, Behavior, Economic, Social

\section{Introduction}

One of the most apparent aspects of a business is advertising. Advertising is the most effective means of reaching out to customers. Customers are more informed about the brands available on the market and the diversity of products available to them thanks to advertising. Everyone, even children, young and old, is exposed to advertising. An average Indian adolescent has seen roughly 3,50,000 commercials by the age of 18 and has spent 2500 to 3000 hours doing so, which is more time than he or she has invested in school.

Advertising is the process of communication that aims to persuade viewers to buy a product or service by providing information and encouraging them to do so. It is regarded as a critical and necessary component for the marketers' and businesses' economic progress (Ryans, 1996).

Advertising's primary goal is to influence purchasing behaviour; nevertheless, this impact on the brand is frequently altered or enhanced by people's recollections. In the mind of the consumer, associations associated to the brand name build memories about the brand (Khan, Siddiqui, Shah \&Hunjra, 2012). These brands have a constant influence on what people think about, evaluate, and ultimately buy (Romaniuk\& Sharp, 2004).

Consumer purchasing behavior has traditionally been given a lot of weight and space in research on the effects of advertising on its efficacy (Ajzen, 2002). The majority of the time, customer purchasing behavior is determined by the buyer's fondness or dislike of the marketed goods (Smith et al., 2006).

Advertising, without a doubt, aids in increasing the number of persons employed. It raises the wages of those who work in this profession. It enables merchants to receive more revenue, which they can put into improving their products and services. However, advertisements do have negative consequences on the business cycle. Consumers may find imported items to be superior to national brands in some cases. This will have an impact on production, which will, in turn, have an impact on the country's GDP (Lee, 2007). The Abundance Principle, which states that generating more items and services than the rate of consumption helps keep consumers informed about their 
options and helps sellers play in a healthy and competitive environment with their self-interest, supports the economic elements.The buyer-seller relationship is maintained if the purchasers are satisfied with what they saw in the advertisement and what they received after purchasing the product. The relationship between the seller and the buyers cannot be healthy if the supplier portrays a false or deceptive image of the goods in the advertisement. These issues can be avoided if the vendor keeps their ads clean and presents the correct product image (Bronner and de Hoog 2014).The use of advertising is critically assessed and even restricted in some cases. Given its persuasive nature, sociologists and religious leaders hold critical views about certain effects of advertising in influencing and transmitting social values. Advertising is criticized because it causes materialism, makes consumers buy products that they do not need, perpetuates stereotypes, affects children in their tender age, and controls the media for its content selection.

Those who are practitioners in the field of advertising support advertising on the basis that it only reflects and not shapes the values of the society in which they live. These values are the result of socialization and acculturation process. Advertising is only one of the environments which has its vast presence and with which the customer has an interaction. (Nielsen 2012).

These issues are largely the ethical concerns of advertising effects and therefore advertisers are expected to keep restrain either in the use of advertising or in the adoption of certain advertising practices. In some cases, the use of advertising in any form is considered unlawful such as when consumers are induced to buy products like cigarettes which are considered as potential health hazard products or when the intention is to mislead the consumers (Gretzel et al. 2006).Advertisements in social and economic aspects were constantly attempting to persuade people to support social and economic reasons such as quitting drugs, quitting smoking, quitting violence, and so on; social advertisements were created by various government and non-government groups.

1. Shabbir, Kirmani, and Hassan (2008) surveyed student's attitudes towards T.V advertisements in Pakistan. Female college students were the only ones who were targeted. In each of the six metropolitan areas, a national investigation was conducted (Karachi, Lahore, Quetta, Peshawar, Rawalpindi, and Islamabad). A total of 400 questionnaires were circulated, with 299 of them being collected. The response rate was $75 \%$, and the results revealed that a larger percentage of people disagree with the claim that television advertisements communicate the truth. Similarly, their findings reveal that students are aware of the irritating aspects of advertisements and believe that the majority of television commercials are offensive and obnoxious.

2. According to Nicholas J. Ashill and UgurYavas (2004) conducted a study in which data was collected via a questionnaire from a sample of 303 Istanbul individuals and 189 New Zealand residents. Advertisements are judged on their social and economic impact by the target audience, and advertising attitudes are shown to have both social and economic elements.

3. Chung-Chuan Yang (2000) the study used a survey method to evaluate college students' perceptions regarding advertising in Taiwan. This study used two American-developed advertising conceptions and their operationalizations: ideas about advertising and attitudes toward advertising in general (AG). $\mathrm{He}$ 
discovered that Taiwanese college students think that advertising enhances a country's economy because it stimulates competition, benefits customers, and raises their living standards. Chung Chuan Yang also discovered that students regard advertising as a valuable source of fashion information that assists them in keeping up with the latest items and services on the market.

4. According to Beard (2003) the poll was carried out at a university in the United States. He used a 26-statement survey questionnaire created by Larkin (1977). He discovered that today's college student believes advertising persuades individuals to buy goods they don't need.

5. Dan Petrovici, SvetlaMarinova, Marin Marinov, and Nick Lee (2007) The research employs a stratified random sample of 947 adult respondents from major urban locations in Bulgaria (507) and Romania (502). (440). As a typical implementation of the reflective indicator model, variables are measured on multi-item scales. According to them, the majority of people (over $80 \%$ ) believe that advertising promotes negative values and messages. In Bulgaria and Romania, they investigated the perceived socio-economic effects of advertising as well as consumer views and attitudes toward advertising.

\section{Objectives of the study}

1. To investigate students' attitudes toward television commercials.

2. To investigate students' attitudes about advertisements from an economic standpoint.

3. To investigate students' attitudes towardsT.V advertisements on social aspects.

4. To compare the attitude of male and female students towards T.V advertisements.

\section{Methodology}

\section{Design of the study}

The descriptive survey method was followed to describe attitudes of students toward T.V advertisements on Economic and Social aspects.

\section{Sample}

A total sample of 100 students from five departments was taken from Panjab University, Chandigarh. From each department 20 students, both male and female were selected.

\section{Tools Used}

The data was gathered from the Panjab University on the subject matter. For this, purpose various meetings, interactions were held with the respondents. For gathering information, a questionnaire was devised and the necessary information was obtained through personal visits \& interaction.

\section{Statistical Techniques Used}

A descriptive Statistics technique was used to analyses the data. Frequency and Percentage were calculated to study the general nature of scores. 


\section{Results and Discussions}

Table I. Distribution of sample based on attitude towards the economic aspect in the TV advertisement

\begin{tabular}{|c|c|c|c|c|}
\hline S. No. & Economic Aspects & Agreed (\%) & Disagreed (\%) & $\begin{array}{l}\text { Neither agree } \\
\text { nor disagree }\end{array}$ \\
\hline 1. & $\begin{array}{l}\text { Does the advertisement increase the price of } \\
\text { the product? }\end{array}$ & $100(100 \%)$ & 0 & 0 \\
\hline 2. & $\begin{array}{l}\text { Advertisement helps you to select the right } \\
\text { product? }\end{array}$ & $40(40 \%)$ & $34(34 \%)$ & $26(26 \%)$ \\
\hline 3. & $\begin{array}{l}\text { In general, Advertisement helps our National } \\
\text { Economy? }\end{array}$ & $60(60 \%)$ & $40(40 \%)$ & 0 \\
\hline 4. & $\begin{array}{l}\text { Through Advertisement, there is a competition } \\
\text { that benefits consumers? }\end{array}$ & $100(100 \%)$ & 0 & 0 \\
\hline 5. & $\begin{array}{l}\text { Do advertisements present the real picture of } \\
\text { the product? }\end{array}$ & $50(50 \%)$ & $50(50 \%)$ & 0 \\
\hline 6. & $\begin{array}{l}\text { Do advertisements just tend to confuse the } \\
\text { consumer? }\end{array}$ & $60(60 \%)$ & $40(40 \%)$ & 0 \\
\hline 7. & $\begin{array}{l}\text { An advertisement is valuable sources of } \\
\text { information? }\end{array}$ & $60(60 \%)$ & $40(40 \%)$ & 0 \\
\hline 8. & $\begin{array}{l}\text { Do advertisements tell the full feature of } \\
\text { products? }\end{array}$ & $60(60 \%)$ & $40(40 \%)$ & 0 \\
\hline 9. & $\begin{array}{l}\text { Advertisement persuades peoples to buy } \\
\text { products which they should not buy? }\end{array}$ & $26(26 \%)$ & $40(40 \%)$ & $34(34 \%)$ \\
\hline 10. & $\begin{array}{l}\text { Do peoples wear branded good because of } \\
\text { Advertisements? }\end{array}$ & $24(24 \%)$ & $50(50 \%)$ & $26(26 \%)$ \\
\hline 11. & $\begin{array}{l}\text { Do advertisements help to know about the new } \\
\text { product? }\end{array}$ & $50(50 \%)$ & $18(18 \%)$ & $32(32 \%)$ \\
\hline 12. & $\begin{array}{l}\text { There should be a ban on Advertisements } \\
\text { harmful or dangerous products? }\end{array}$ & $100(100 \%)$ & 0 & 0 \\
\hline 13. & $\begin{array}{l}\text { Does advertisement help raise our standard of } \\
\text { living? }\end{array}$ & $100(100 \%)$ & 0 & 0 \\
\hline 14. & Advertisements are good for the consumer? & $70(70 \%)$ & $30(30 \%)$ & 0 \\
\hline Averag & & 64.28 & 27.28 & 8.42 \\
\hline
\end{tabular}


Table I reveals that the distribution of students based on attitude towards T.V. advertisements on Economic aspects in which:

1. All the students were agreed that the Advertisement increased the price of the product.

2. Less than fifty percent of students were agreed that Advertisement helps you to select the right product while one third disagreed whereas one-fourth students revealed that they had neither agreed nor disagreed about this statement.

3. 60 percent of students were agreed that in general Advertisement helps our National Economy and 40 percent disagreed with this statement.

4. All the students were agreed that through Advertisement there is a competition which benefits the consumer.

5. Half of the students were agreed while half of the respondents thought that advertisements portray the true picture of a product, the other half disagreed

6. 60 percent of students were agreed that Advertisements just tend to confuse the consumer and on the other hand Advertisements are also a valuable source of information while the remaining 40 percent disagreed with both the states.

7. More than fifty percent of students were agreed that Advertisements tell the full feature of products while 40 percent disagreed with this statement.

8. Only 26 percent of students were agreed that Advertisements persuades peoples to buy products which they should not buy while 40 percent disagreed with this and 34 percent were neither agreed nor disagreed.

9. 24 percent of students revealed that Peoples wear branded good because of Advertisements while half disagreed with this and 26 percent were neither agreed nor disagreed with this statement.

10. Half of the students were agreed that Advertisements help to know about a new product while 18 percent disagreed and the remaining 32 percent were neither agreed nor disagreed about this statement.

11. All the students were agreed Advertisements with harmful or dangerous products should be banned, but Advertisements also enable us to better our standard of living.

12. 70 percent of students were agreed that Advertisements are good for the consumer while 30 percent disagreed with this statement.

Thus, it is concluded that averagely:

- $\quad 64.28$ students were agreed.

- $\quad 27.28$ students disagreed.

- Whereas 8.42 students were neither agreed nor disagreed regarding the statements given on Economic aspects in the advertisement. 
Table II. Distribution of students on the basic attitude towards TV advertisements on the social aspect

$\begin{array}{llll}\text { S. No. Social Aspects } & \text { Agreed (\%) } & \text { Disagreed (\%) } & \begin{array}{l}\text { Neither agree } \\ \text { nor disagree }\end{array}\end{array}$

\begin{tabular}{|c|c|c|c|c|}
\hline 1. & $\begin{array}{l}\text { Too many Advertisements today were false } \\
\text { and misleading? }\end{array}$ & $56(56 \%)$ & $44(44 \%)$ & 0 \\
\hline 2. & $\begin{array}{l}\text { Advertisements were now silly and } \\
\text { ridiculous? }\end{array}$ & $50(50 \%)$ & $30(30 \%)$ & $20(20 \%)$ \\
\hline 3. & $\begin{array}{l}\text { The use of sexual appeals in advertisements } \\
\text { produces potentially negative side effects. }\end{array}$ & $100(100 \%)$ & 0 & 0 \\
\hline 4. & Do advertisements lead to a rise in crime? & 0 & $100(100 \%)$ & 0 \\
\hline 5. & $\begin{array}{l}\text { Do advertisements lead to violence against } \\
\text { women? }\end{array}$ & 0 & $100(100 \%)$ & 0 \\
\hline 6. & $\begin{array}{l}\text { Do advertisements create conflict between } \\
\text { parents and students over the purchase of } \\
\text { products advertised? }\end{array}$ & $100(100 \%)$ & 0 & 0 \\
\hline 7. & $\begin{array}{l}\text { Do advertisements promote unsafe behaviour } \\
\text { among students? }\end{array}$ & $60(60 \%)$ & 0 & $40(40 \%)$ \\
\hline 8. & $\begin{array}{l}\text { Advertisements can be accused of lacking } \\
\text { social responsibility? }\end{array}$ & $100(100 \%)$ & 0 & 0 \\
\hline 9. & Do advertisements exploit society? & $100(100 \%)$ & 0 & 0 \\
\hline 10. & $\begin{array}{l}\text { Do advertisements portray women as the } \\
\text { weaker sex? }\end{array}$ & 0 & $100(100 \%)$ & 0 \\
\hline 11. & $\begin{array}{l}\text { Do advertisements undermine traditions and } \\
\text { culture? }\end{array}$ & $100(100 \%)$ & 0 & 0 \\
\hline
\end{tabular}

Table II reveals that the distribution of students based on their attitude towards social aspects in T.V. advertisement in which

1. 56 percent of students were agreed that too many Advertisements today were false and misleading while 44 percent disagreed with this statement.

2. Half of the students were agreed that advertisement is now silly and ridiculous while 30 percent disagreed and 20 percent were neither agreed nor disagreed about this statement. 
3. All the students were agreed that using sexual appeals in commercials has the potential to have negative consequences and to cause disagreement amid parents and students over purchase of marketed products.

4. All the students disagreed that advertisement lead to a rise in crime, lead to violence against women, and portray women as the weaker sex.

5. All the students were agreed with the following statements that Advertisements cause of lacking social responsibility, exploitation of society, and undermine traditions and culture.

6. 60 percent of students were agreed that Advertisements promote unsafe behavior among students while 40 percent were neither agreed nor disagreed about this statement.

Thus, it is concluded that averagely:

- $\quad 60.54$ students were agreed.

- 34 students disagreed.

- Whereas 5.45 students were neither agreed nor disagreed regarding the statements given on Social aspects in the advertisement.

Table III. To compare the attitude of male and female students towards T.V advertisements on Economic Aspect

\begin{tabular}{|l|l|l|l|l|l|}
\hline \multirow{2}{*}{ Response } & \multicolumn{2}{|l|}{ Mean } & \multicolumn{2}{l|}{ S.D } & \multirow{2}{*}{ T-Ratio } \\
\cline { 2 - 5 } & Male & Female & Male & Female & \\
\hline Agree & 33.07 & 33.35 & 12.42 & 12.51 & 0.95 \\
\hline Disagree & 13.57 & 13 & 9.43 & 9.41 & 0.86 \\
\hline $\begin{array}{l}\text { Neither agree or nor } \\
\text { disagree }\end{array}$ & 3.35 & 3.64 & 6.30 & 6.42 & 0.90 \\
\hline
\end{tabular}

Thus, it is concluded that while comparing the attitude of male and female students towards T.V advertisement on Economic Aspect our calculated t-value is less than the table value, so the value is not significant.

Table IV. To compare the attitude of male and female students towards T.V advertisements on Social Aspect

\begin{tabular}{|l|l|l|l|l|l|}
\hline \multirow{2}{*}{ Response } & \multicolumn{2}{|l|}{ Mean } & \multicolumn{2}{l|}{ S.D } & \multirow{2}{*}{ T-Ratio } \\
\cline { 2 - 5 } & Male & Female & Male & Female & \\
\hline Agree & 30.09 & 30.27 & 20.74 & 20.73 & 0.98 \\
\hline Disagree & 17.09 & 16.90 & 21.40 & 21.39 & 0.98 \\
\hline $\begin{array}{l}\text { Neither agree or nor } \\
\text { disagree }\end{array}$ & 2.81 & 2.81 & 6.42 & 6.27 & 1 \\
\hline
\end{tabular}




\section{AJAST}

Asian Journal of Applied Science and Technology (AJAST)

Volume 5, Issue 3, Pages 111-119, July-September 2021

Thus, it is concluded that while comparing the attitude of male and female students towards T.V advertisement on

Social Aspect our calculated value is less than the table value so it is not significant.

\section{Educational Implications}

The results indicate that the economic aspect was that most people think that Advertisement increased the price of the product, through advertisement; there is a competition which benefits consumers.

Advertisements for unsafe or dangerous products should be prohibited; nonetheless, advertisements contribute to increase our standard of living. The main finding of the social aspect was that the majority of students agreed that the use of sexual appeals in advertisements has potentially negative side effects; advertisements cause conflict between parents and students over the purchase of advertised products; advertisements can be accused of lacking social responsibility, exploiting society, and undermining traditions and culture; advertisements can be accused of lacking social responsibility, exploiting society, and undermining traditions and culture.

Advertisements, as per the students, cause an increase in crime, violence against women, and portray women as the weaker sex. On the other hand, there are some significant positive aspects that can aid in the development of society and technological advancements, employment, providing self-interested buyers with choices, encouraging healthy competition, raising living standards, and providing information on social, economic, and health issues.

\section{Declarations}

\section{Source of Funding}

This research did not receive any grant from funding agencies in the public, commercial, or not-for-profit sectors.

\section{Competing Interests Statement}

The authors declare no competing financial, professional and personal interests.

\section{Ethical Approval}

Not applicable.

\section{Consent for publication}

Authors declare that they consented for the publication of this research work.

\section{References}

Ashil, N.J., Yavas, U. (2005), "Dimensions of Advertising Attitudes, Congruence between Turkish and New Zealand Consumers", Marketing Intelligence \& Planning, 23(4): 340-349

Beard, F. K. (2003), “College student Attitude towards Advertising's Ethical, Economic and Social Consequence". Journal of Business Ethics, 217-228.

Chung-Chuan Yang (2000), “Taiwanese student's attitudes towards and beliefs about advertising”, Journal of marketing communications, 6: 171-183. 
Petrovici, D., Marinova, S., Marinov, M. and Lee, N. (2007), "Personal uses and perceived social-economic effects of advertising in Bulgaria and Romania", International Marketing Review, Vol. 24 No. 5, pp. 539-562.

Shabbir, M.S., Kimani, S., Hassan, H.F. (2008), "Children Attitude towards TV Advertisements in Pakistan", European Journal of Scientific Research, 21(4): 693-699.

\section{Websites}

https://www.managementstudyguide.com/social-economic-aspects-advertising.htm

https://edurev.in/studytube/Lecture-15-Social-and-Econimic-Aspects-of-Advertis/e577adb1-25fd-4d35-a67a-2bfa 3ea78b7a_p

https://www.academia.edu/3409945/Consumer_Attitude_towards_TV_Advertising_Based_Upon_Consumers_A ge_and_Gender

https://pdfs.semanticscholar.org/c95c/717fbb29f583159a4f9b50a23640edca7b11.pdf

file://C:/Users/admin/Downloads/ST09_Khattak_Khan.pdf

https://www.academia.edu/3409945/Consumer_Attitude_towards_TV_Advertising_Based_Upon_Consumers_A ge_and_Gender

http://zenithresearch.org.in/images/stories/pdf/2012/April/ZIJMR/19_ZIJMR_APRIL12_VOL2_ISSUE4.pdf

http://nectar.northampton.ac.uk/11692/1/Mortimer_Kathleen_2016_Students_attitude_towards_advertising_in_th e_new_digital_environment.pdf

file://C:/Users/admin/Downloads/ST09_Khattak_Khan\%20(1).pdf

https://www.researchgate.net/publication/241567956_Dimensions_of_advertising_attitudes_Congruence_betwee n_Turkish_and_New_Zealand_consumers 